INVENTORY:Jurnal Akuntansi

ISSN 2597-7202 (Print); ISSN 2613-912X (Online)

Vol. 5, No. 2, Oktober 2021, Hal 87-93

Tersedia Online: http://e-journal.unipma.ac.id/index.php/inventory

\title{
Determinan Keberhasilan UMKM Berbasis Ekonomi Kreatif di Kabupaten Bantul
}

\author{
Sri Widodo ${ }^{1}$, Afri Ovita ${ }^{2}$ \\ ${ }^{1}$ Program Sarjana Akuntansi, Universitas PGRI Yogyakarta \\ Email: Sriwidodo0102@gmail.com \\ ${ }^{2}$ Program Sarjana Akuntansi, Universitas PGRI Yogyakarta \\ Email: Afriiovita@gmail.com
}

\begin{abstract}
Abstrak
Usaha mikro, kecil dan menengah menjadi salah satu sektor ekonomi yang memiliki peran cukup signifikan terhadap perekonomian negara, tak terkecuali negara Indonesia. Di Indonesia UMKM mempunyai peranan meningkatkan Produk Domestik Bruto (PDB) negara dan menyerap tenaga kerja yang dapat mengurangi terjadinya pengangguran. Tujuan dilakukannya penelitian ini untuk mengetahui pengaruh penggunaan informasi akuntansi, modal usaha, dan umur usaha terhadap keberhasian usaha UMKM berbasis ekonomi kreatif di Kabupaten Bantul. Sampel dalam penelitian ini dipilih dengan purposive sampling, sebanyak 197 responden. Teknik analisis yang digunakan dalam penelitian ini menggunakan analisis regresi linear berganda. Hasil penelitian membuktikan bahwa penggunaan informasi akuntansi dan umur usaha berpengaruh terhadap keberhasilan usaha, sedangkan modal usaha tidak berpengaruh terhadap keberhasilan usaha. Implikasi dilakukanya penelitian ini bagi UMKM agar dapat meningkatkan penggunaan informasi akuntansi serta memaksimalkan penggunaan modal usaha.
\end{abstract}

Kata Kunci: Informasi akuntansi, modal usaha, umur usaha, keberhasilan UMKM.

\section{Determinants of MSME Succes Based on Creative Economy in Bantul District}

\begin{abstract}
Micro, small and medium enterprises are one of the economic sectors that have a significant role in the country's economy, and Indonesia is no exception. In Indonesia, MSMEs have a role in increasing the country's Gross Domestic Product (GDP) and absorbing labor which can reduce unemployment. The purpose of this study was to determine the effect of using accounting information, business capital, and business age on the success of creative economy-based SMEs in Bantul Regency. The sample in this study was selected by purposive sampling, as many as 197 respondents. The analysis technique used in this study uses multiple linear regression analysis. The results of the study prove that the use of accounting information and business age have an effect on business success, while business capital has no effect on business success. The implications of this research are for MSMEs to increase the use of accounting information and maximize the use of business capital.
\end{abstract}

Keywords: Accounting information, business capital, age of business, success of MSMEs

\section{PENDAHULUAN}

Pada tahun 1998 krisis moneter yang melanda Indonesia telah berdampak pada terpuruknya perekonomian nasional, yang menjadikan sektor UMKM sebagai salah satu sektor yang paling banyak diminati kalangan masyarakat di Indonesia (Diansari \& Rahmantio, 2019). Sektor UMKM merupakan salah satu sektor penting dalam perekonomian negara dikarenakan perannya yang cukup besar terhadap perekonomian negara dalam hal meningkatan PDB dan penyedia lapangan pekerjaan. Hal ini dikarenakan dalam melakukan pengelolaan UMKM tidak cukup sulit untuk dilakukan berbagai klangan serta tidak membutuhkan biaya yang sangat besar (Bee \& Christian, 2016). Pentingnya peranan UMKM terhadap perekonomian bangsa diperlukan adanya dukungan dari berbagai pihak agar tercapainya keberhasilan usaha (Rianto \& Hidayatulloh, 2020).

Kabupaten Bantul menjadi salah satu kabupaten yang dinobatkan sebagai kabupaten mandiri kreatif sektor kriya menurut Kementrian Pariwisata dan Ekonomi kreatif. Hal ini dapat dilihat bahwa sektor kerajinan di Kabupaten Bantul menyumbang $80 \%$ produk kerajinan untuk Daerah Istimewa Yogyakarta (dpmpt.bantulkab.go.id). Dengan banyaknya sektor ekonomi

DOI: $10.25273 /$ inventory.v5vi2i.8936

Copyright (C) 2021 Penulis

Sume rights reserved. 
kreatif sektor kerajinan di Kabuaten Bantul berdampak positif terhadap perkembangan UMKM berbasis ekonomi kreatif subsektor kriya. Maraknya UMKM sektor kriya di Kabupaten Bantul mencerminkan tercapainya keberhasian usaha pada UMKM ekonomi kreatif sektor kriya.

Keberhasilan usaha dipengaruhi beberapa faktor, salah satunya adalah faktor penggunaan informasi akuntansi. Penggunaan informasi akuntansi dapat dimanfaatkan oleh pelaku usaha sebagai dasar pengambilan keputusan dalam mengelola usaha, keberhasilan sebuah usaha dapat ditentukan dengan adanya pengambilan keputusan bisnis yang tepat (Rianto \& Hidayatulloh, 2020). Walaupun peran penggunaan informasi akuntansi cukup penting bagi pelaku usaha namun dalam praktiknya masih banyak permasalahan yang terjadi seperti kesulitan dalam memahami penerapan akuntansi dengan baik dan rendahnya kemauan untuk melakukan pencatatan akuntansi yang disebabkan oleh beberapa hal diantaranya rendahnya tingkat pendidikan, minimnya pemahaman tentang Standar Akuntansi Keuangan (SAK) dari Owner, dan belum tersediaan peraturan mengenai kewajiban untuk menyusun laporan keuangan bagi UMKM (Wibowo \& Kurniawati, 2015).

Modal usaha menjadi salah satu faktor yang dapat mendorong keberhasilan usaha. Modal menjadi salah satu hal yang cukup penting bagi sebuah usaha saat mendirikan atau menjalankan usaha. Keberadaan modal sangat diperlukan dalam mendirikan dan menjalankan usaha, namun yang menjadi persoalan adalah bagaimana agar dapat mengelola modal secara optimal (Rumerung, 2018). Keberadaan modal dalam sebuah usaha menjadi salah satu permasalah bagi pelaku usaha. keberadaan modal yang terlalu besar melebihi kebutuhan usaha dapat menambah pembiayan, terlebih apabila modal yang diperoleh berasal dari pinjaman. Keberadaan modal yang terlalu sedikit juga dapat menyulitkan UMKM dalam menjalankan usaha. fenomena lain yang ditemui pada UMKM mengenai permodalan adalah sulitnya akses permodalan yang dapat digunakan sebagai tambahan modal usaha dikarenakan kebanyakan usaha belum melakukan pencatatan usaha sesuai dengan apa yang di isyaratkan oleh lembaga keuangan serta tidak stabilnya keberadaan modal dalam usaha (Arliani et al., 2019; Safitri \& Setiaji, 2018).

Umur usaha menjadi salah satu faktor yang mempengaruhi keberhasilan usaha. Umur usaha merupakan lamanya sebuah usaha berkembang, bertahan, dan tetap berdiri sehingga mampu bersaing di dunia usaha (Rianto \& Hidayatulloh, 2020). Umur usaha dapat berdampak terhadap UMKM yang mengakibatkan terjadinya perubahan tingkat kemampuan dalam pengambilan keputusan, pola pikir, dan keterampilan dalam menjalankan (Soraya \& Amir, 2016). Penelitian ini dilakukan mengingat pentingnya peranan UMKM dalam kegiatan perekonomian negara sebagai penyedia lapangan pekerjaan serta beragamnya hasil penelitian terdahulu yang membahas mengenai faktor-faktor yang mempengaruhi keberhasilan UMKM. Penelitian ini dilakukan pada UMKM berbasis ekonomi kreatif di Kabupaten Bantul.

\section{KAJIAN TEORI DAN PENGEMBANGAN HIPOTESA Usaha Mikro, Kecil dan Menengah}

Menurut Undang-undang Nomor 20 Tahun 2008, UMKM merupakan usaha produktif mandiri yang dijalankan oleh perorangan atau badan usaha yang bukan bagian dari anak atau cabang perusahaan. Kriteria usaha mikro mempunyai Aset $\leq 50$ Juta dan omzet $\leq 300$ juta, dan omzet sampai 50 Miliar untuk usaha menengah.

\section{Keberhasilan Usaha}

Keberhasilan usaha merupakan keberhasilan sebuah usaha dalam mencapai tujuan usahanya (Herawaty \& Yustien, 2019). Secara umum, keberhasilan usaha dapat dilihat dari dua indikator yaitu peningkatan usaha dan perluasan usaha (Rini \& Laturette, 2016). Peningkatan usaha merepresentasikan meningkatnya usaha menjadi lebih baik, sementara perluasan usaha diartikan dengan memperbesar atau memperluas usaha. Keberhasilan usaha dapat dilihat dengan adanya kenaikan modal, kenaikan pendapatan, kenaikan kapasitas penjualan, kenaikan produksi serta tenaga kerja (Suryana, 2014). 


\section{Ekonomi Kreatif}

Ekonomi kreatif merupakan aktivitas ekonomi yang berasal dari kekayaan intelektual kreatif yang berasal dari warisan budaya, ilmu pengetahuan, dan teknologi (Howkins, 2011). Di Indonesia subsektor ekonomi kreatif terbagi kedalam 16 sektor yaitu: industri periklanan, arsitektur, barang seni, kriya, desain, fashion, film, animasi dan video, permainan interaktif, seni pertunjukan, musik, penerbitan dan percetakan, layanan komputer dan piranti lunak, televisi dan radio, riset dan pengembangan industri kreatif, kuliner, aplikasi dan game developer.

\section{Penggunaan Informasi Akuntansi}

Informasi akuntansi merpuakan seluruh informasi dari suatu entitas yang dapat dimanfaatkan dalam pengambilan keputusan bisnisnya. Pelaku usaha dapat memanfaatkan Informasi akuntansi dalam melakukan penyusunan proyeksi kebutuhan uang kas, mengontrol biaya, serta mengukur produktivitas bisnis (Deswira, 2009). Penggunaan informasi akuntansi sendiri merupakan tindakan pelaku usaha memanfaatkan informasi akuntansi dalam mengambil keputusan diantara beberapa alternatif pilihan (Wibowo \& Kurniawati, 2015).

\section{Modal Usaha}

Modal usaha menjadi salah satu hal yang cukup penting untuk mendirikan usaha dan menjalankan usaha. Modal merupakan uang atau segala sesuatu yang menghasikan barang atau jasa (Bambang rianto, 2010). Modal non materi juga sangat diperlukan dalam menjalankan sebuah usaha, meliputi pengetahuan, kreativitas dan kemauan (Anthony, 2018). Berdasarkan kriteria yang dimiliki UMKM tidak memerlukan modal yang cukup besar.

\section{Umur Usaha}

Umur usaha merupakan lamanya sebuah usaha berkembang, bertahan, dan tetap berdiri sehingga dapat tetap bersaing di dunia usaha (Rianto \& Hidayatulloh, 2020). Umur usaha mencerminkan pola pikir dan perilaku sebuah usaha dalam menjalankan usahanya. Semakin lama umur usaha daat memberikan dampak positif terhadap pola pikir sebuah bisnis dalam menjalankan kegiatan bisnisnya. Sebuah usaha akan tetap bertahan jika pelaku usaha mengambil keputusan usaha yang dapat memeperpanjang umur usahanya (Soraya \& Amir, 2016).

\section{KERANGKA KONSEPTUAL DAN PENGEMBANGAN HIPOTESA}

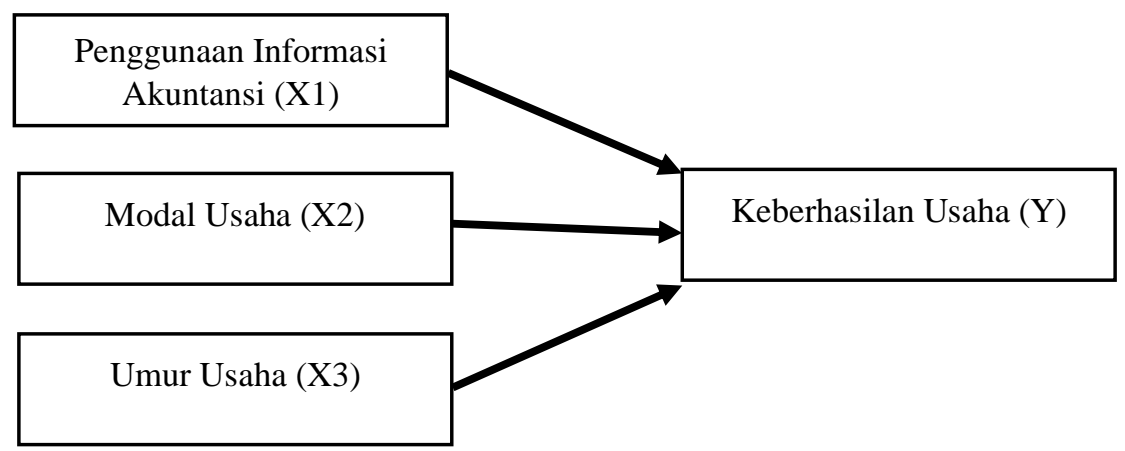

Gambar 1. Kerangka Konseptual Penelitian

Penggunaan informasi akuntansi berupa tindakan menggunakan informasi akuntansi dalam mengambil keputusan bisnis diantara pilihan berbagai alternatif tindakan (Wibowo \& Kurniawati, 2015). Pelaku bisnis dapat memanfaatkan informasi akuntansi dalam proses perencaan, pengelolaan maupun evaluasi bisnis yang dapat menunjang keberhasian usaha (Candra et al., 2020). Hasil penelitian menyatakan bahwa penggunaan informasi akuntansi berpengaruh terhadap keberhasilan usaha (Diansari \& Rahmantio, 2019; Rianto \& Hidayatulloh, 2020). Hipoteis penelitian di rumuskan sebagai berikut:

H1: Penggunaan Informasi Akuntansi berpengaruh terhadap keberhasilan 
usaha.

Modal usaha dapat diartikan sebagai sumber dana yang digunakan oleh pelaku usaha untuk mendirikan, menjalankan, dan mengembangkan usahanya (Arliani et al., 2019). Modal usaha menjadi salah satu aspek penting untuk UMKM dalam menjalankan usahanya agar tetap berdiri. Modal usaha dapat diperoleh dari tabungan, menjalin kerja sama dengan investor, atau dengan cara meminjam uang kepada lembaga keuangan seperti Bank (Guli dan Uli Wildan Nuryanto, 2017). Ketepatan jumlah modal usaha yang dibutuhkan oleh UMKM sangat diperlukan dalam menjamin kelancaran kegiatan operasional usaha (Firdarini \& Prasetyo, 2020). Hasil penelitian menunjukkan bahwa modal usaha berpengaruh terhadap keberhasilan usaha (Apriliani \& Dr. Widiyanto, MBA., 2018; Diansari \& Rahmantio, 2019; Safitri \& Setiaji, 2018). Hipotesis penelitian dirumuskan sebagai berikut:

H2: Modal Usaha berpengaruh terhadap keberhasilan usaha.

Umur usaha merupakan lamanya sebuah usaha berdiri, berkembang dan bertahan ditengah tingginya persaingan di dunia usaha. Umur usaha akan dapat meningkat jika sebuah usaha melakukan pengelolaan secara baik dan melakukan pembukuan secara rapi (Soraya \& Amir, 2016). Hasil penelitian menunjukkan bahwa umur usaha berpengaruh terhadap keberhasilan usaha (Rianto \& Hidayatulloh, 2020; Utami, 2018). Hipotesis penelitian dirumuskan sebagai berikut:

H3: Umur usaha berpengaruh terhadap keberhasilan usaha.

\section{METODE PENELITIAN}

\section{Populasi dan Sampel}

Populasi penelitian ini adalah seluruh UMKM di Kabupaten Bantul. Sampel dipilih menggunakan metode purposive sampling dengan kriteria (1) UMKM yang memiliki kriteria penghasilan dan jumlah aset sesuai dengan Undang-Undang No. 20 Tahun 2008, (2) Responden adalah pemilik UMKM, (3) UMKM yang sudah melakukan pencatatan atas bisnisnya, (4) UMKM ekonomi kreatif subsektor kriya. Pengumpulan data dalam penelitian ini menggunakan kuesioner yang disebar kepada responden secara langsung. Kuesioner disebarkan pada 200 UMKM ekonomi kreatif sektor kriya di Kabupaten Bantul.

\section{Pengukuran Variabel}

Pengukuran variabel keberhasilan usaha menggunakan 7 indikator yang dikembangkan oleh (Wibowo \& Kurniawati, 2015). Indikator yang digunakan yaitu: 1) bertambahnya karyawan; 2) meningkatnya omzet penjualan; 3) meningkatnya modal; 4) meningkatnya pendapatan; 5) meningkatnya volume penjualan; 6) meningkatnya jumlah produksi; 7) meningkatnya jumlah alat produk.

Pengukuran variabel penggunaan informasi akuntansi menggunakan 11 indikator yang dikembangkan oleh (Wibowo \& Kurniawati, 2015). Indikator yang digunakan yaitu: 1) penggunaan informasi akuntansi untuk proyeksi keuangan dimasa yang akan datang; 2) mengontrol biaya; 3) mengukur produktivitas; 4) meningkatkan produktivitas; memberikan dukungan terhadap proses produksi; 6) penggunaan infromasi operasi; 7) penggunaan infromasi akuntansi manajemen; 8) penggunaan infromasi akuntansi keuangan; 9) penggunaan informasi statututory accounting; 10) penggunaan infromasi budgetary; 11) penggunaan infromasi additional accounting.

Pengukuran variabel modal usaha menggunakan 2 indikator yang dikembangkan oleh (Herawaty \& Yustien, 2019). Dua indikator yang digunakan meliputi 1) modal dalam bentuk materi (uang); 2) modal dalam bentuk non materi. Pengukuran variabel keberhasilan usaha, penggunaan informasi akuntansi, dan modal usaha menggunakan Skala Likert dengan skala 1-5. Sedangkan pengukuran variabel umur usaha menggunakan skala ordinal dengan kriteria 
sebagai berikut: 1) 0-5 tahun; 2) > 5-10 tahun; 3) > 10-15 tahun; 4) > 15-20 tahun; 5) lebih dari 20 tahun (Rianto \& Hidayatulloh, 2020).

\section{HASIL DAN PEMBAHASAN}

Statistik kuesioner yang didapatkan dari penelitian ini sejumlah 200 kuesioner yang dibagikan dan kembali sebanyak 200 buah. Terdapat 3 buah kesioner yang tidak bisa digunakan karena tidak memenuhi kriteria. Hasil deskripsi responden secara lengkap ditampilkan pada tabel 1.

Tabel 1. Karakteristik Responden

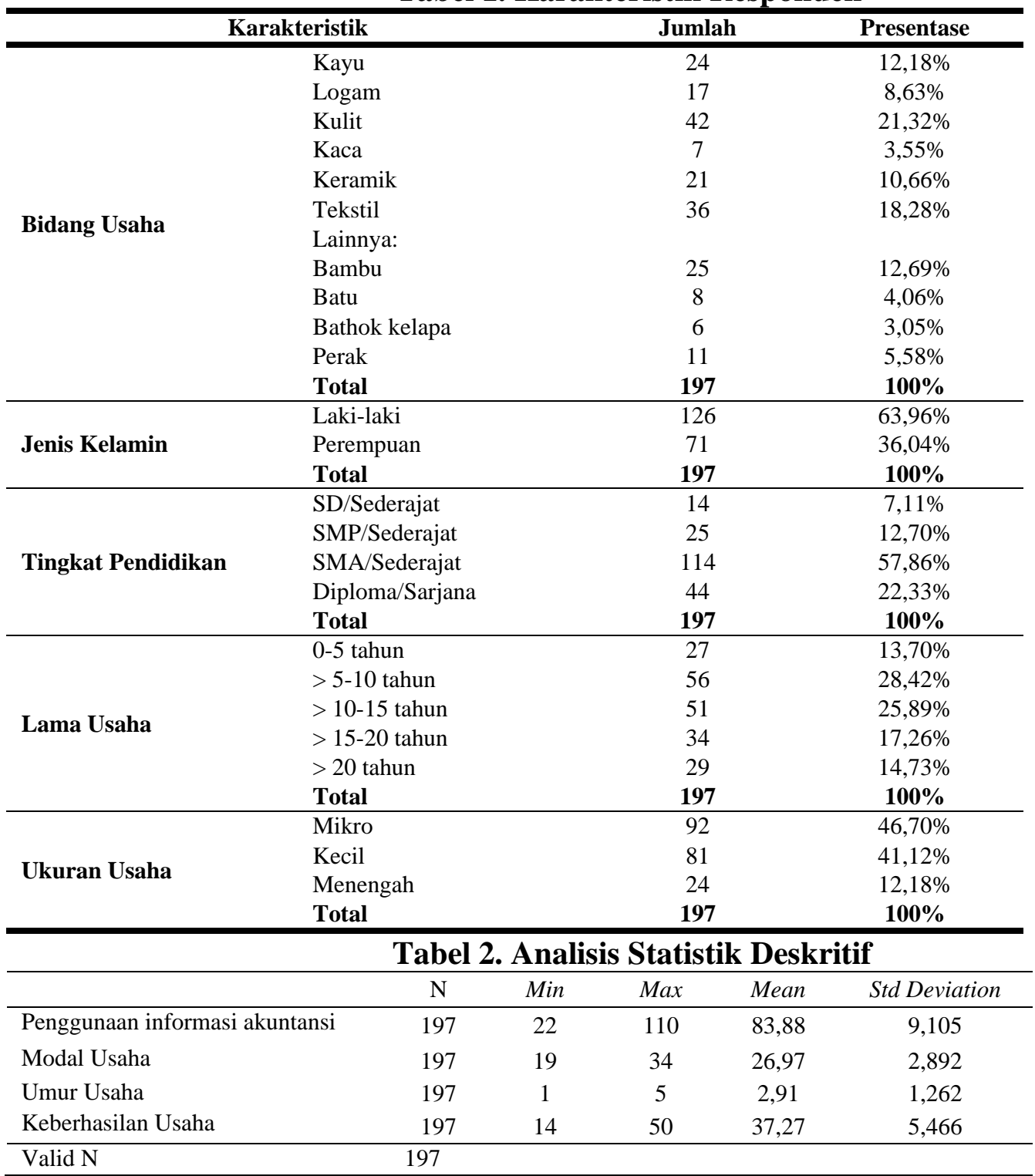

Analisis statsitik deskriptif digunakan untuk memberikan gambaran penilaian responden terhadap variabel penelitian. Berdasarkan tabel 2, disimpulkan bahwa seluruh variabel yang digunakan dalam penelitian memiliki mean > standar deviasi. Hal ini mengidentifikasikan bahwa penyebaran data menunjukan nilai yang normal dan tidak menghasilkan bias.

Uji validitas dan uji reliabilitas dilakukan untuk menguji instrumen. Uji validitas diukur dengan nilai signifikansi < 0,05 (Ghozali, 2018), sedangkan uji reiabilitas menggunakan nilai cronbach > 0,70 (Ghozali, 2018). Tabel 5, menampilkan contoh hasil uji validitas dari variabe keberhasilan usaha. Sementara tabel 6, menampilkan hasil uji reliabilitas seluruh variabel. 
Tabel 3. Uji Validitas

\begin{tabular}{|c|c|c|c|c|c|c|c|c|c|c|c|}
\hline & (1) & (2) & (3) & (4) & (5) & (6) & (7) & (8) & (9) & (10) & Total \\
\hline N.1 & 1 & & & & & & & & & & \\
\hline N.2 & 0,623 & 1 & & & & & & & & & \\
\hline N.3 & 0,678 & 0,777 & 1 & & & & & & & & \\
\hline N.4 & 0,473 & 0,576 & 0,640 & 1 & & & & & & & \\
\hline N.5 & 0,306 & 0,316 & 0,241 & 0,307 & 1 & & & & & & \\
\hline N.6 & 0,566 & 0,572 & 0,738 & 0,521 & 0,293 & 1 & & & & & \\
\hline N.7 & 0,612 & 0,681 & 0,760 & 0,54 & 0,371 & 0,826 & 1 & & & & \\
\hline N.8 & 0,633 & 0,640 & 0,749 & 0,654 & 0,421 & 0,767 & 0,895 & 1 & & & \\
\hline N.9 & 0,648 & 0,665 & 0,773 & 0,641 & 0,351 & 0,795 & 0,870 & 0,905 & 1 & & \\
\hline N.10 & 0,376 & 0,447 & 0,421 & 0,450 & 0,435 & 0,477 & 0,560 & 0,530 & 0,583 & 1 & \\
\hline Total & 0,758 & 0,803 & 0,861 & 0,744 & 0,510 & 0,827 & 0,903 & 0,907 & 0,913 & 0,667 & 1 \\
\hline
\end{tabular}

\begin{tabular}{ll}
\hline \multicolumn{1}{c}{ Tabel 4. Uji Reliabilitas } \\
\hline \multicolumn{1}{c}{ Variabel } & Cronbach Alpha \\
\hline Penggunaan Informasi Akuntansi (X1) & 0,914 \\
Modal Usaha (X2) & 0,710 \\
Keberhasilan Usaha (Y) & 0,931 \\
\hline
\end{tabular}

Signifikansi $>0,70$

\begin{tabular}{lcccc}
\hline & \multicolumn{5}{c}{ Tabel 5. Hasil Uji Hipotesis } \\
\hline \multicolumn{1}{c}{ Variabel } & B & T & P Value & Hasil \\
\hline (constant) & 21,181 & 4,963 & 0,000 & \\
Penggunaan Informasi Akuntansi & 0,220 & 5,207 & 0,000 & H1 diterima \\
Modal Usaha & $-0,023$ & $-0,169$ & 0,866 & H2 ditolak \\
Umur Usaha & $-0,589$ & $-2,044$ & 0,042 & H3 diterima \\
\hline F Hitung & $: 11,329$ & & & \\
Sig. F & $: 0,000$ & & & \\
Adjusted $R$ Square & $: 0,137$ & & & \\
\hline
\end{tabular}

Berdasarkan tabel 5 diatas menunjukan bahwa nilai Adjusted R Square yang dihasilkan sebesar 0,137. Hal ini menunjukan bahwa variabel dependen dalam penelitian dijelaskan oleh ketiga variabel independen sebesar $13,7 \%$, sedangkan $86,3 \%$ lainnya dijelaskan oleh variabel lain diluar penelitian ini.

Tabel 5 menjelaskan bahwa variabel penggunaan informasi akuntansi berpengaruh terhadap keberhasilan usaha dengan nilai $\mathrm{t}$ sebesar 4,963 dan $\mathrm{p}$ value $0,000<0,05$, sehingga $\mathrm{H} 1$ diterima. Hasil penelitian ini konsisten dengan penelitian (Diansari \& Rahmantio, 2019; Rianto \& Hidayatulloh, 2020; Wibowo \& Kurniawati, 2015) yang mengemukakan bahwa adanya pengaruh penggunaan informasi akuntansi berpengaruh terhadap keberhasilan usaha. Penggunaan informasi akuntansi dapat digunakan oleh pihak UMKM dalam pengambilan keputusan dalam merencanakan, menjalankan maupun evaluasi aktivitas usaha.

Variabel modal usaha tidak berpengaruh terhadap keberhasilan usaha dengan niai t sebesar $-0,169$ dan $p$ value 0,866 > 0,05, sehingga H2 ditolak. Penelitian ini tidak konsisten dengan temuan (Apriliani \& Dr. Widiyanto, MBA., 2018; Diansari \& Rahmantio, 2019) bahwa modal usaha berpengaruh terhadap keberhasilan usaha, namun penelitian ini sejalan dengan penelitian (Herawaty \& Yustien, 2019) yang menyatakan bahwa modal usaha tidak berpengaruh terhadap keberhasilan usaha. Alasan menolak hipotesis karena masih banyak pelaku usaha sektor ekonomi kreatif di Kabupaten Bantul yang mengandalkan modal pribadi untuk mendirikan dan menjalankan usaha dibandingkan modal dari perbankan dan koperasi.

Variabel umur usaha berpengaruh terhadap keberhasilan usaha dengan niai t sebesar -2,044 dan $\mathrm{p}$ value $0,042<0,05$, sehingga $\mathrm{H} 2$ diterima. Hasil penelitian ini sejalan dengan penelitian (Rianto \& Hidayatulloh, 2020; Utami, 2018) yang mengemukakan bahwa umur usaha berpengaruh terhadap keberhasilan usaha. Pelaku usaha yang memiliki umur usaha lebih lama memiliki keunggulan karena mempunyai pengalaman yang lebih banyak dibandingkan dengan usaha yang baru beroperasi. Pelaku usaha yang menginginkan usahanya tetap berjalan maka pemilik usaha diharuskan agar dapat mengambil keputusan usaha yang dapat menambah umur usaha (Soraya \& Amir, 2016).

\section{Kesimpulan, Keterbatasan dan Saran}

Berdasarkan hasil penelitian yang dilakukan dapat disimpulkan bahwa penggunaan informasi akuntansi dan umur usaha berpengaruh terhadap keberhasilan usaha, sedangkan variabel odal usaha tidak berpengaruh 
terhadap keberhasilan usaha. Implikasi dilakukanya penelitian ini bagi UMKM agar dapat mengoptimalkan penggunaan informasi akuntansi serta memaksimalkan penggunaan modal usaha baik modal pribadi maupun modal eksternal. Peneitian ini dilakukan hanya terbatas tiga variabel saja yaitu penggunaan informasi akuntansi, modal usaha, dan umur usaha. Penelitian selanjutnya dapat menambahkan variabel independen yang mempengaruhi keberhasilan usaha, seperti pengetahuan atau pemahaman akuntansi, karakteristik wirausaha, sumber daya manusia berdasarkan tingkat pendidikan (Wibowo \& Kurniawati, 2015). Metode pengumpulan data hanya menggunakan kuesioner, sehingga diharapkan penelitian selanjutnya dapat menambahkan metode pengumpulan data dengan wawancara. Objek penelitian hanya terbatas pada UMKM berbasis ekonomi kreatif subsektor kriya di Kabuaten Bantul. Oleh karena itu, untuk penlitian selanjutnya agar dapat memperluas objek penelitian,

\section{DAFTAR PUSTAKA}

Apriliani, M. F., \& Dr. Widiyanto, MBA., M. . (2018). Pengaruh karakteristik wirausaha, modal usaha dan tenaga kerja terhadap keberhasilan UMKM batik. Economic Education Analysis Journal, 7(2), 761-776. http://journal.unnes.ac.id/sju.index.php/eeaj

Arliani, L., Indrayani, L., Tripalupi, L. E., Studi, P., Ekonomi, P., \& Ganesha, U. P. (2019). Pengaruh perilaku pelaku usaha dan modal usaha terhadap keberhasilan UMKM di Desa Tukad Sumaga Kecamatan Gerogak Kabupaten Buleleng. Jurnal Pendidikan Akuntansi, 11(2), 427-436.

Bee, A., \& Christian, G. (2016). Peran penggunaan informasi akuntansi dalam pengambilan keputusan untuk menunjang keberhasilan usaha. Jurnal EBBANK, 7(2), 77092.

Candra, M., Rahayu, R., \& Yohana, D. (2020). Faktor-faktor yang mempengaruhi penggunaan informasi skuntansi dengan ketidakpastian lingkungan bisnis sebagai variabel moderasi ( Pada UKM di Kota Padang ). Journal of Economic and Business, 4(September), 353-360. https://doi.org/10.33087/ekonomis.v4i2.146

Diansari, R. E., \& Rahmantio, R. (2019). Faktor keberhasilan usaha pada UMKM industri sandang dan kulit di Kecamatan Wirobrajan Kota Yogyakarta. Journal of Business and Information System, 2(1), 55-62. https://doi.org/10.36067/jbis.v2i1.60

Firdarini, K. C., \& Prasetyo, A. S. (2020). Pengaruh penggunaan informasi akuntansi dan manajemen modal kerja pelaku UMKM terhadap keberhasilan usaha dengan umur usaha sebagai variabel pemoderasi (Studi kasus pada industri kreatif di Yogyakarta). Jurnal STIE Semarang, 12(1).

Guli dan Uli Wildan Nuryanto. (2017). Analisis keberhasilan usaha cuci sepeda motor di Kota Serang dilihat dari besarnya modal, kualitas pelayanan dan harga. Islamiconomic, 8(2), 141-168.

Herawaty, N., \& Yustien, R. (2019). Pengaruh modal, penggunaan informasi dan karakteristik wirausaha terhadap keberhasilan usaha (Survei pada Usaha Rumahan Produksi Pempek di Kota Jambi). Jurnal Ilmiah Akuntansi Dan Finansial Indonesia, 3(1), 63-76.

Rianto, D., \& Hidayatulloh, A. (2020). Penggunaan informasi akuntansi dan umur usaha mendorong keberhasilan usaha mikro kecil dan menengah batik di Kota Yogyakarta. SAINS: Jurnal Manajemen Dan Bisnis, XII(2), 299-312.

Rini, A. D., \& Laturette, K. (2016). Relevansi sikap berakuntansi pelaku UMKM muda dan penggunaan informasia akuntansi terhadap keberhasilan usaha. Riset Akuntansi Dan Keuangan, 12(12), 85-93.

Rumerung, D. (2018). Analisis tingkat keberhasilan usaha usaha kecil mikro dan menengah di Kabupaten Maluku Tengah. Jurnal SOSOQ, 5, 75-92.

Safitri, H., \& Setiaji, K. (2018). Pengaruh modal usaha, dan karakteristik wirausaha terhadap perkembangan usaha mikro kecil di Desa Kedungleper Kecamatan Bangsi Kabupaten Jepara. Economic Education Analysis Journal, 7(2), 792-800.

Soraya, E. A., \& Amir, M. (2016). Faktor- faktor yang mempengaruhi kebutuhan standar akuntansi keuangan entitas tanpa akuntabilitas publik. Accounting Analysis Journal, 5(1), 1-8.

Utami, H. T. (2018). Pengaruh pengetahuan pemilik, skala usaha, dan umur Usaha terhadap keberhasilan kinerja usaha dengan penggunaan informasi akuntansi sebagai variabel moderasi (Survei pada pemilik usaha UKM Makanan Khas di Kabupaten Banyumas). El-Jizya: Jurnal Ekonomi Islam, 6(1), $23-48$. https://doi.org/10.24090/ej.v6i1.2044

Wibowo, A., \& Elisabeth Penti Kurniawati. (2015). Pengaruh penggunaan informasi akuntansi terhadap keberhasilan usaha kecil menengah (Studi pada sentra konveksi di Kecamatan Tingkir Kota Salatiga). Jurnal Ekonomi Dan Bisnis, XVIII(2), 107-126.

Zulia Hanum. (2013). Pengaruh persepsi pengusaha kecil, atas informasi akuntansi keuangan terhadap keberhasilan perusahaan (Survei pada usaha-usaha kecil di Kota Medan)l. Jurnal Riset Akuntansi Dan Bisnis, 13(September), 217-250. 